\title{
Geology of the Fort a la Corne Kimberlites, Saskatchewan
}

\author{
Scott Smith, B.H. ${ }^{1}$, Orr, R.G. ${ }^{2}$, Robertshaw, P. ${ }^{3}$, and Avery, R.W. ${ }^{3}$
}

1. Scott-Smith Petrology Inc., 2555 Edgemont Boulevard, North Vancouver, BC, Canada, V7R 2M9

2. Mindoro Resources Ltd., \#1910 - 10180101 Street, Edmonton, Alberta, Canada, T5J 3S4

3. Uranerz Exploration and Mining Limited, \#1300-410 22nd Street East, Saskatoon, Saskatchewan, Canada, S7K 5T6

Introduction : The Fort a la Corne (FALC) Cretaceous (98-94Ma.) kimberlite province was discovered under $100 \mathrm{~m}$ of glacial overburden by Uranerz Exploration and Mining Ltd. in 1988 (Lehnert-Thiel, et al., 1992). Since then evaluation of these bodies has been continuing with joint venture partners Cameco Corp., Monopros Ltd. and Kensington Resources Ltd. The province occurs $80 \mathrm{~km}$ east of Prince Albert in Saskatchewan and includes at least 71 magnetically defined bodies which range in size to over $100 \mathrm{ha}$. So far 69 of these anomalies have been confirmed as kimberlites by drilling. These bodies are located in a $45 \times 30 \mathrm{~km}$ zone. Significant amounts of diamonds have been recovered but no economic deposits have been found yet. This study investigated 44 drillholes containing approximately $5 \mathrm{~km}$ of kimberlite core from 25 bodies.

Geological setting : The kimberlites were emplaced into poorly consolidated Cretaceous sediments comprising $\pm 100 \mathrm{~m}$ of clayey fine material, silts and sandstone (Mannville Formation; $\pm 119-100 \mathrm{Ma}$ ) and $\pm 100 \mathrm{~m}$ of marine shales (Ashville Formation; $\pm 100-91 \mathrm{Ma}$ ). The Mannville formed in coastal marine, subaerial flood plain and/or lacustrine environments. The shales were deposited towards the edge of the Western Interior Seaway, a broad shallow epicontinental sea with migrating shorelines. The Mannville unconformably overlies $400 \mathrm{~m}$ of Palaeozoic sediments which are dominated by indurated carbonates below which is the Precambrian basement. The Cretaceous sediments adjacent to the main kimberlites correlate with the regional stratigraphy showing that they are in situ and undisturbed (J. Christopher, unpublished report).

Classification : These bodies are classified as crater-facies kimberlites. No hypabyssal or diatremefacies rocks have been encountered. The FALC rocks are typical Group 1 kimberlites.

Crater size, shape and formation : The FALC kimberlites are shallow saucer to champagne-glass shaped bodies with diameters mainly of 500 to $1300 \mathrm{~m}$ and depths ranging up to $200 \mathrm{~m}$. The body shapes, flaring towards surface with low depth to diameter ratios, are similar to maars and must represent explosion craters excavated into only the Cretaceous sediments. The lack of xenoliths within the crater infill show that little or none of the resulting material was deposited back within the craters. This feature is comparable to maars where most of the crater material is deposited in crater rim base surge deposits. Based on the nature of the base surge, maars are generally considered to result from phreatomagmatic processes. No extra-crater deposits have been found at FALC to allow further evaluation of the crater forming events. However, a porous sandstone unit at the base of the Mannville is a modern aquifer which probably became saturated following the marine transgression at the beginning of the Ashville. This aquifer is the point from which many of the craters appear to flare. Also in contrast to many of the kimberlite pipes in southern Africa, there is no evidence of the development of any diatremes or root zones (sensu Field and Scott Smith, this volume -a) below the craters. The unusual southern African diatreme emplacement processes which are driven by juvenile gases in a closed system (Field and Scott Smith, this volume - b) have not taken place at FALC. It is proposed that the FALC bodies were formed by phreatomagmatic maar- 
sedimentation during a regression within the upper Ashville Formation. This suggests that the main process of deposition was pyroclastic airfall. Although the eruptions were predominantly subaerial, there is evidence for some subaqueous deposition of the airfall material into small volumes of standing water which must be crater lakes.

The styles of eruption were very variable. The less explosive activity ranged from Hawaiian to Strombolian-type eruptions resulting in the formation of amoeboid lapilli tuffs with bedding up to perhaps $12-15 \mathrm{~m}$ thick. Other much more explosive eruptive styles must be kimberlite-specific and reflect the unusual properties of these magmas, mainly their low viscosities and high carbon dioxide contents. These eruptions resulted from the rapid degassing of some of the FALC magmas above the vent, a process which is the extrusive equivalent of the intrusive diatreme formation in other kimberlites. Similar pelletal lapilli to those characteristic of diatreme-facies kimberlites were produced. These explosive eruptions must have formed high energy eruption columns. The abundant carbon dioxide in the eruption column derived from the degassing as well as the high specific gravity of the clasts must have limited the height of the column and inhibited movement of the pyroclastic material from the vent resulting in the formation of the unique mega-graded beds within the craters. The unusual olivine tuffs are thought to form by the physical separation of the crystals from very low viscosity magmas. Kimberlites, being some of the most crystal-rich and fluidal magmas known, are good candidates for the formation of such crystal tuffs. The ash produced in the higher energy eruptions was often removed, presumably by wind action.

Conclusions : The main FALC kimberlites formed by two distinct processes : crater formation and crater infilling. The crater formation is suggested to result from maar-like phreatomagmatic processes with the resulting material deposited mainly as extra-crater deposits. The craters were subsequently rapidly infilled by subaerial primary pyroclastic processes ranging from HawaiianStrombolian to a much more explosive kimberlite-specific eruption style. This emplacement model is different from the classic southern African diatreme model. It is suggested that the FALC model is a second model for kimberlites with the differences primarily reflecting the near surface country rock geology. The data for FALC, validate, rather than negate, the classic diatreme model (Field and Scott Smith, this volume - b). The FALC volcanism lasted at least $25 \mathrm{Ma}$. but the main kimberlite crater formation was confined to the last 5-10Ma..

\section{References}

Demaiffe, D., Fieremans, M., and Fieremans, C., 1991, The kimberlites of central Africa: A review. In A.B. Kampunzu and R.T. Lubala, Eds., Magmatism in extensional structural settings. The Phanerozoic Plate, p.537-559. Springer Verlag.

Leckie, D.A., Kjarsgaard, B.A., Bloch, J., McIntyre, D., McNeil, D., Stasiuk, and Heaman, L., 1997, Emplacement and re-working of Cretaceous diamond-bearing crater-facies kimberlite of central Saskatchewan, Canada. GSA Bulletin, v. 109, p. 1000-1020.

Lehnert-Thiel, K., Loewer, R., Orr, R., and Robertshaw, P., 1992, Diamond-bearing kimberlites in Saskatchewan, Canada: the Fort a la Corne case history. Exploration and Mining Geology, v. 1, p. 391-403.

Scott Smith, B.H., Orr, R.G., Robertshaw, P., and Avery, R.W., 1995, Geology of the Fort a la Corne kimberlites, Saskatchewan. Extended Abstracts of the 6th International Kimberlite Conference, Novosibirsk, Russia, Siberian Branch of Russian Academy of Sciences, p. 543-545.

This abstract is based on the same study and similar to that of Scott Smith et al. (1995). 
like processes. The remarkable similarity in both the geological setting and the nature of the kimberlites at FALC and Mbuji-Mayi in Zaire (Demaiffe et al., 1991) cannot be a coincidence. The evidence presented here for the FALC craters contradicts the Leckie et al. (1997) model which proposes that the bulk of the volcanism formed positive relief conformable tephra cones during the Mannville. The FALC craters formed during the Ashville but were preceded by common small kimberlites which comprise conformable graded beds up to $5 \mathrm{~m}$ thick of unreworked pyroclastic airfall material. These kimberlites occur throughout the Mannville and were deposited onto the subaerial flood plains without the formation of craters. If the aquifer at the base of the Mannville only became saturated at the beginning of the Ashville, it is consistent with the presence of maarlike craters only being formed during the Ashville.

Age : Stratigraphic constraints suggest that all the FALC kimberlite eruptions span at least $25 \mathrm{Ma}$. The main kimberlite crater formation was probably confined to the last $\pm 5-10 \mathrm{Ma}$ (perhaps $98-91$ Ma.; supported by isotopic data) while the small precursors formed from 119 to at least $100 \mathrm{Ma}$.

Main constituents and rock types : These loosely packed, clast supported, poorly sorted volcaniclastic kimberlites are composed predominantly of a mixture of juvenile lapilli and single crystals which are mainly olivine (clasts mostly $<10 \mathrm{~mm}$ in size, up to $10 \mathrm{~cm}$ ). The lapilli vary in shape from spherical or ovoid to irregular-curvilinear or amoeboid showing that they formed from very fluidal magmas. The groundmasses are quenched and sometimes vesicular but no true glass is observed. The main constituents of these kimberlites formed by pyroclastic processes. The interclast matrix is composed of mainly serpentine, carbonate and magnetite. The proportion of juvenile lapilli to single grains of olivine varies so the main rock types range from juvenile lapilli tuffs (or coarse ash) to unusual crystal or olivine tuffs (or coarse ash). Most rocks have undergone some sorting. Overall at FALC ash and coarse ash sized clasts, comprising kimberlite matrix and often single olivine phenocrysts, are not common. Some, but not all, of the drillcores display well developed plane parallel normal graded bedding. Individual beds vary from a few millimetres to at least $90 \mathrm{~m}$ in thickness. The latter appear to be unique in the geological record. Bedding dips vary from horizontal to $80^{\circ}$ and some disturbed bedding is present.

Near surface emplacement : In contrast to the crater formation, the crater infilling results from magmatic eruptions. Many features show that resedimentation of the pyroclastic material was not an important process. These features include: the low particle density; the presence of occasional welding or molding of plastic lapilli; bomb sags and possible draping; in situ impact fragmented xenolithic bombs; the occurrence of composite lapilli showing that mixed lapilli populations result from recycling not resedimentation; the presence of different phases of eruption with associated marker horizons and sharp internal contacts; evidence of large scale sorting resulting in the overall paucity of ash and the presence of mega-graded beds; the very significant lack of abrasion or breakage of most and often fragile juvenile and xenolithic clasts; the lack of cross bedding and other sedimentary features; and the overall lack of incorporation of crater wall material.

The kimberlites were emplaced at a time of overall marine deposition leading to suggestions that they are likely to have erupted in submarine conditions. Features within the FALC kimberlites, however, show that most of the pyroclastic activity was subaerial. These features include the occurrence of fluidal not quenched lapilli shapes, welding and molding, vesicular lapilli, poor sorting of a wide range of clast sizes, lack of resedimentation and a general lack of fines. There is also stratigraphic evidence for a $\pm 3 \mathrm{Ma}$ hiatus (approximately $94.5-91 \mathrm{Ma}$ ) in the marine 